\title{
Application of Ecological Architecture Concept in Student Dormitory in Yogyakarta
}

\author{
Case Study University Student Dormitory in Yogyakarta
}

\author{
Jarwa Prasetya Sih Handoko, ST, M.Sc.
}

\begin{abstract}
Ecological architecture is an architectural concept that emphasizes harmony between the built environment and the natural conditions in the vicinity. This alignment is necessary at this time, with the declining quality of environment marked by numerous environmental damage caused to the construction of both buildings and other facilities. This phenomenon must be addressed jointly by both architects, government and society. Construction of the facility either settlements or other functions must consider harmony with the natural conditions around the building. This is done to prevent the acceleration of environmental damage caused by the construction of buildings and other facilities. Yogyakarta is one of the major cities in Indonesia with high population growth of student. With the number of students increasing in number from year to year. Yogyakarta is known as a student city in Indonesia. There are many universities that set up campus in this city. So that the provision of occupancy for student be something important and a priority. This leads to increased demand for community housing including university student dormitory. Addressing the needs of student housing is continuously carried out by the universities in Yogyakarta. Therefore, it is necessary to have a study that evaluates the application of the concept of ecological architecture in student dormitory in the city of Yogyakarta. This study is a comparative study conducted descriptive methods associated with application of the concept of ecological architecture in the student dormitory design. This study takes a case study of 3 (three) student dormitory in Yogyakarta. With this paper is expected to provide a general description of the application of the concept of ecological architecture in the student dormitory design in Yogyakarta and find out what aspects of ecological architecture that has been applied to the student dormitory design. From this study it can be concluded that the university student dormitory in the city of Yogyakarta has been implementing the concept of ecological architecture in several aspects. This is influenced by site conditions, location and shape of site. Recommendations from this study is that the design of the student dormitory buildings should be able to optimize the application of the concept of ecological architecture on all aspects of the design.
\end{abstract}

Keywords-Aplication, Ecological Architecture, Student Dormitory, Yogyakarta.

\section{INTRODUCTION}

$\mathrm{E}$ COLOGICAL architecture is an architectural concept that emphasizes harmony between the built environment and the natural conditions in the vicinity. This alignment is

Jarwa Prasetya Sih Handoko is with the Department of Architecture, Faculty of Civil Engineering and Planning, Universitas Islam Indinesia, Yogyakarta, Indonesia (corresponding author's phone: +62 8156851825; email:jarwa.prasetya@uii.ac.id). necessary at this time, with the declining quality of environment marked by numerous environmental damage caused to the construction of both buildings and other facilities. This phenomenon must be addressed jointly by both architects, government and society. Along with it a decline in the quality of our environment and the emergence of damage to the environment around us. One of the causes of environmental damage is a building that does not consider the natural conditions where the building is located. So that the construction of the building in a location often cause damage to the local environment.

Construction of the facility either settlements or other functions must consider harmony with the natural conditions around the building. This is done to prevent the acceleration of environmental damage caused by the construction of buildings and other facilities.

Therefore, it is necessary to have a study that evaluates the application of the concept of ecological architecture in university student dormitory in the city of Yogyakarta. This study is a comparative study with descriptive methods were implemented related to student dormitory building design and application of the concept of ecological architecture in the draft. This study takes a case study of 3 (three) student dormitory in Yogyakarta. With this paper is expected to provide a general description of the application of the concept of ecological architecture in the student dormitory design in Yogyakarta and find out what aspects of ecological architecture that has been applied to the design of student dormitory.

\section{II.LITERATURE REVIEW}

\section{A. Student Dormitory}

The dormitory is called the dormitory term derived from the Latin dormitorium which means a large room containing a number of beds or residential buildings with rooms containing many beds. The notion of dormitory according to Echols dan Shadily (1975) dormitory is a student dormitory.

\section{B. Ecological Architecture}

Ecology is usually understood as the things that are affecting all types of living things (plants, animals, human beings) and the environment (light, temperature, precipitation, humidity, topography, etc.). Similarly, the process of birth, 
life, alternation of generations, a nd death are all part of human knowledge.

The process continues and is named as 'natural law'. (Frick, 1998). According to Wikipedia (2015) as follows:

1) The walls, the roof of a building in accordance with his duties, must protect the heat rays, wind and rain.

2) Energy intensity either contained within the building materials used during construction should seminal possible.

3) Building as far as possible be directed according to the East-West orientation with the North-South section receives natural light without glare

4) The walls of a building should be able to provide protection against heat. Heat absorption and thickness of the wall in accordance with the needs of the climate / temperature space in it.

The building naturally air refresher attention can save a lot of energy. The term ecology first introduced by Ernst Haeckel, an expert of zoology in 1869 as a science of the interaction of all living species and the environment. Meaning of the word ecology in the Greek is "oikos" is household or how to live and "logos" science or scientific nature. Ecology can be defined as the study of the interrelationships between living things and their environment (Frick, 1998).

Actually, eco-architecture contains also the parts of the biological architecture (architecture humanitarian attention to health), architecture alternative, architecture sun (by utilizing solar energy), architecture bionic (civil engineering and construction that takes into account human health), as well as the biological development .Eko-architecture does not specify what should happen in architecture because there is no binding characteristics as standard or standard size. However, ecoarchitecture includes the harmony between man and his natural environment.

Heinz Frick (1998) argues that the ecological architecture does not specify what should happen in architecture, because there is no binding characteristics as a standard or standard size. However covers harmony between man and nature. Ecological architecture contains also the dimension of time, the natural, socio-cultural, space and building techniques. Therefore, a holistic ecological architecture is a very broad term and contains all the fields. The principle of building ecological architecture according to Frick (1998), among others :

1) Adjustments to the local natural environment.

2) Conserve natural energy sources are not renewable and energy savings.

3) Maintaining the source environment (air, soil, water), maintain and improve the natural circulation.

4) Reduce dependence on the central system and wastes energy.

5) Possible occupants generate their own daily needs.

6) Utilizing the natural resources around the area of planning for building systems. Both related to construction materials or for building utilities (energy sources and energy supply)

Ecological building criteria according to Frick (1998) are :

1. Creating a green area between the building area.

2. Choose the appropriate building site.

3. Using locally made building materials.

4. Using natural ventilation in buildings.

5. Select the surface layer of the walls and ceiling of the room that is able to drain the water vapor.

6. Ensure that the building does not cause environmental problems.

7. Using renewable energy.

8. Creating a barrier-free building (can be used all ages).

\section{AIM}

1) Knowing whether student dormitory in Yogyakarta have applied the concept of Ecological architecture in design.

2) What kind of the criteria for Ecological architecture concept that has been already applied in the design of Student Dormitory in Yogyakarta..

\section{METHOD}

This study is a comparative study with a descriptive method using the existing library with case studies of real condition of the student dormitory building. Descriptive research is research that seeks to describe a symptom, events, events that occur at the present time.

This study was conducted associated with building design flats and Ecological architecture aspects in the design of the student dormitory. This study takes a case study 3 (three) student dormitory in Yogyakarta.

1) Universitas Islam Indonesia Student Dormitory, Yogyakarta,

2) Bulaksumur Residence, Universitas Gadjah Mada, Yogyakarta dan

3) Ratnaningsih Residence, Universitas Gadjah Mada, Yogyakarta.

With this paper is expected to provide a general description of the application of the concept of Ecological architecture in the student dormitory design in Yogyakarta.

Descriptive research is generally done with the main objective, which is to systematically describe the facts and characteristics of the object or subject under study accurately. The primary data of direct interviews and field observations as well as secondary data from design drawings and other necessary documents used in the analysis of this writing. 


\section{V.RESULT}

\section{A. Universitas Islam Indonesia Student Dormitory,} Yogyakarta

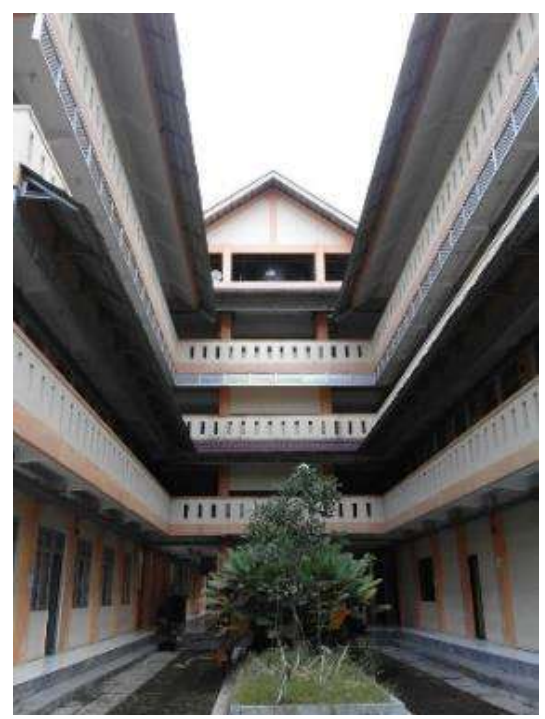

Fig 1. Universitas Islam Indonesia Student Dormitory, Yogyakarta. Source : Author Documentation, 2017.

Student Dormitory The Islamic University of Indonesia is located in the south of the campus of Universitas Islam Indonesia. There are a total of 2 building blocks each facing northwest and southeast. This building consists of 4 floors of buildings that have the number of types of room units that is 1 typical, including from the 2nd floor to the 4th floor with typical layout of the building plan.

\section{B. Bulaksumur Residence, Universitas Gadjah Mada} Student Dormitory, Yogyakarta.

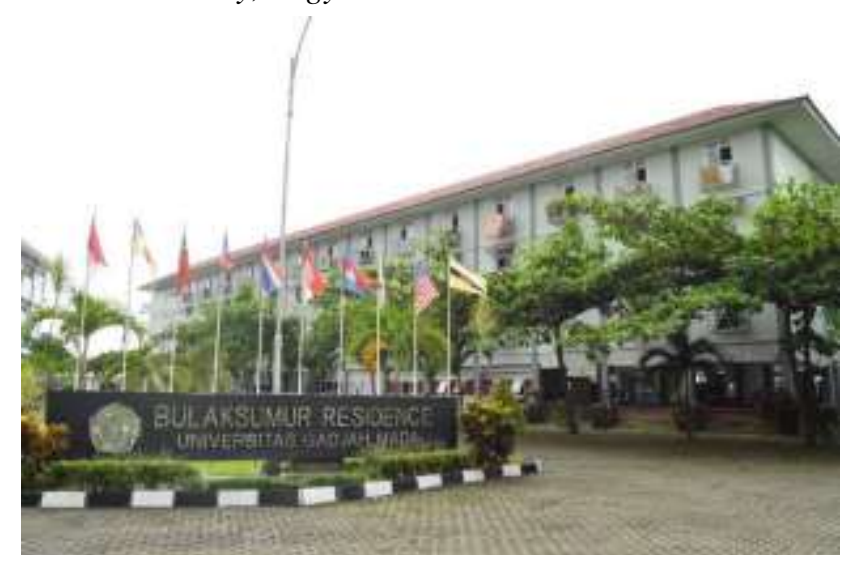

Fig 2. Bulaksumur Residence, Yogyakarta. Source : Author Documentation, 2017.

This female college student resides in the middle of the campus location of Gajah Mada University. This dormitory has 2 blocks of occupancy in which each block is $\mathrm{H}$-shaped as is the case with UII Student Dormitory. Each block has a long and elongated oriented building character facing Southwest and Northeast. This building has 4 levels of flooring, 2 to 4 floors typical and its room type unit.

\section{C.Ratnaningsih Residence, Universitas Gadjah Mada} Student Dormitory, Yogyakarta.

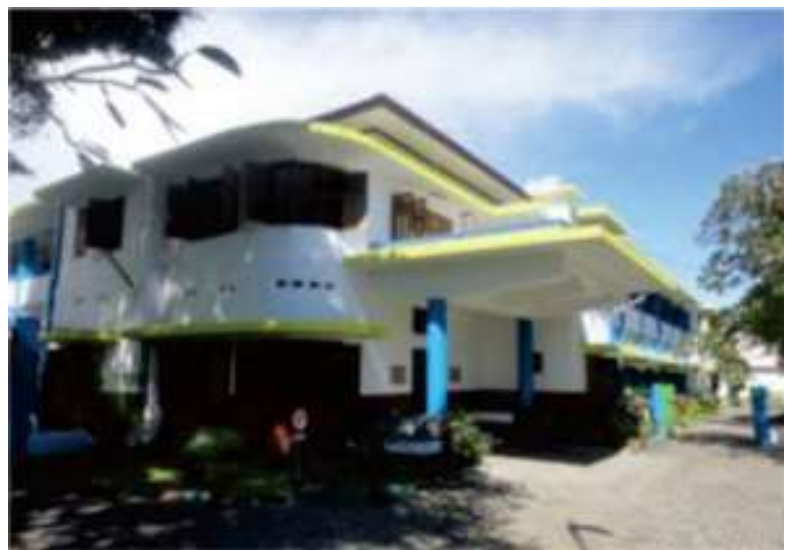

Fig 3. Ratnaningsih Residence, Yogyakarta. Source : Author Documentation, 2017.

Ratnaningsih Residence Gadjah Mada University is a residential facility provided exclusively for female students. Ratnaningsih Residence is a historic building that was inaugurated by Ir. Soekarno, the first Indonesia president in 1954.

(http://asramaugm.com/?page=profil-asrama-ratnaningsih, 2017)

\section{Comparative Case Studies}

Primary data and secondary data obtained previously were then analyzed based on several criteria in the concept of ecological architecture derived from the above literature review which includes:

1) Creating a green area between the building area.

2) Choose the appropriate building site.

3) Using locally made building materials.

4) Using natural ventilation in buildings.

5) Select the surface layer of the walls and ceiling of the room that is able to drain the water vapor.

6) Ensure that the building does not cause environmental problems.

7) Using renewable energy.

8) Creating a barrier-free building (can be used all ages). 
TABLE 1.

COMPARATIVE STUdy ECOLOGICAL ARChiteCTURE CONCEPT In STUDENT DORMITORY.

\begin{tabular}{|c|c|c|c|c|}
\hline No. & $\begin{array}{l}\text { Ecological } \\
\text { Architecture Criteria }\end{array}$ & $\begin{array}{lrr}\text { Universitas Islam Indonesia } \\
\text { Student Dormitory }\end{array}$ & Bulaksumur Residence & Ratnaningsih Residence \\
\hline 1. & $\begin{array}{l}\text { Creating green areas } \\
\text { in the building area. }\end{array}$ & $\begin{array}{l}\text { The park is in the courtyard. } \\
\text { - Not to hold urban farming } \\
\text { efforts. }\end{array}$ & $\begin{array}{l}\text { - The park is in the building yard. } \\
\text { - Not to hold urban farming } \\
\text { efforts. }\end{array}$ & $\begin{array}{l}\text { In these towers create a } \\
\text { garden around the towers } \\
\text { with footpaths, the creation } \\
\text { of the corner of the park, } \\
\text { greening fence, the selection } \\
\text { of plants according to size } \\
\text { and location. } \\
\text { - It has been held limited } \\
\text { urban farming efforts. }\end{array}$ \\
\hline 2. & $\begin{array}{l}\text { Choosing a suitable } \\
\text { building site }\end{array}$ & $\begin{array}{l}\text { - Sub Urban location and not in } \\
\text { a fertile agricultural region. }\end{array}$ & $\begin{array}{l}\text { Urban location, near campus } \\
\text { main facilities and not in a } \\
\text { fertile agricultural region. }\end{array}$ & $\begin{array}{l}\text { Urban location, near campus } \\
\text { location and not in a fertile } \\
\text { agricultural region. }\end{array}$ \\
\hline 3. & $\begin{array}{l}\text { Using locally made } \\
\text { building materials. } \\
\text { Utilizing the natural } \\
\text { resources around the } \\
\text { area of planning for } \\
\text { building systems. }\end{array}$ & $\begin{array}{l}\text { - Use of natural building } \\
\text { materials that undergo a } \\
\text { simple transformation } \\
\text { (bricks) } \\
\text { - Not to use recyling materials } \\
\text { (waste) } \\
\text { - Using a synthetic material } \\
\text { for the structure and roof } \\
\text { covering. }\end{array}$ & $\begin{array}{l}\text { - Using building materials that } \\
\text { can be reused (stone) } \\
\text { - Using the composite } \\
\text { construction material } \\
\text { (reinforced concrete) and } \\
\text { precast material. } \\
\text { - Not to use recyling materials } \\
\text { (waste) } \\
\text { - Using a synthetic material for } \\
\text { the structure and roof covering. }\end{array}$ & $\begin{array}{l}\text { - Use of natural building } \\
\text { materials that undergo a } \\
\text { simple transformation } \\
\text { (bricks) } \\
\text { - Not to use recyling materials } \\
\text { (waste) } \\
\text { - Using a synthetic material } \\
\text { for the structure and roof } \\
\text { covering. }\end{array}$ \\
\hline 4. & $\begin{array}{l}\text { Using natural } \\
\text { ventilation in Building. }\end{array}$ & $\begin{array}{l}\text { - The orientation of the } \\
\text { northwest and southeast. } \\
\text { - Letter O building with inner } \\
\text { courtyard. }\end{array}$ & $\begin{array}{l}\text { - The orientation of the east } \\
\text { facing west. } \\
\text { - } \quad \text { Rectangular building }\end{array}$ & $\begin{array}{l}\text { - Mass L-shaped building } \\
\text { - The building is L-shaped and } \\
\text { thin, making it easier } \\
\text { ventilation. }\end{array}$ \\
\hline 5. & $\begin{array}{l}\text { Choosing wall and } \\
\text { ceiling surface that can } \\
\text { drain the water vapor. }\end{array}$ & $\begin{array}{l}\text { The surface of the walls and } \\
\text { ceilings have not been using } \\
\text { the buildings layer greening } \\
\text { efforts. }\end{array}$ & $\begin{array}{l}\text { The surface of the walls and } \\
\text { ceilings have not been using } \\
\text { the buildings layer greening } \\
\text { efforts. }\end{array}$ & $\begin{array}{l}\text { - The surface of the walls and } \\
\text { ceilings have not been using } \\
\text { the buildings layer greening } \\
\text { efforts. }\end{array}$ \\
\hline 6. & $\begin{array}{l}\text { Ensure that the building } \\
\text { does not cause } \\
\text { environmental } \\
\text { problems. }\end{array}$ & $\begin{array}{l}\text { - Land is land bordering the } \\
\text { river. Once the public } \\
\text { square. }\end{array}$ & $\begin{array}{l}\text { - Land is land bordering } \\
\text { the river and the highway. } \\
\text { Once the public square. So } \\
\text { that construction of flats } \\
\text { do not create new } \\
\text { problems in society. }\end{array}$ & $\begin{array}{l}\text { - Land was once the land is } \\
\text { infertile and unproductive. } \\
\text { So that the existence of flats } \\
\text { utilize unused land. }\end{array}$ \\
\hline 7. & $\begin{array}{l}\text { Using renewable } \\
\text { energy. }\end{array}$ & $\begin{array}{l}\text { have not been designed to use } \\
\text { energy sources other than the } \\
\text { country's electricity }\end{array}$ & $\begin{array}{l}\text { have not been designed to use } \\
\text { energy sources other than the } \\
\text { country's electricity. }\end{array}$ & $\begin{array}{l}\text { have not been designed to use } \\
\text { energy sources other than the } \\
\text { country's electricity. }\end{array}$ \\
\hline 8. & $\begin{array}{l}\text { Creating a barrier-free } \\
\text { building }\end{array}$ & $\begin{array}{l}\text { Provides the stairs, and } \\
\text { elevators to facilitate the } \\
\text { transport of goods in the } \\
\text { building. }\end{array}$ & $\begin{array}{l}\text { Provides the stairs, and elevators } \\
\text { to facilitate the transport of } \\
\text { goods in the building }\end{array}$ & $\begin{array}{l}\text { - Provides the stairs, and } \\
\text { elevators to facilitate the } \\
\text { transport of goods in the } \\
\text { building }\end{array}$ \\
\hline
\end{tabular}

\section{CONCLUSION}

From this study it can be concluded that the student dormitory in Yogyakarta city has implemented the concept of ecological architecture in several aspects. This is influenced by site conditions, location and shape of the tread footprint.

1) Aspect of creating green areas in the building area, flat buildings towers create a garden around the towers with footpaths, the selection of plants according to size and location.

2) Aspect of choosing a suitable building site, flat has the urban location and not in a fertile agricultural region.

3) Aspect of using a synthetic material for the structure and roof covering. There are using locally made building materials, utilizing the natural resources around the area of planning for building systems, using building materials that can be reused, using natural building materials and composite construction material and not to use recyling materials.

4) Aspect of using natural ventilation in Building. Flat buildings have the orientation of the east facing west and have rectangular building shape.

5) Aspect of ensurement of the building does not cause environmental problems. Flat buildings use the infertile and unproductive land. So that the existence of flats utilize unused land.

6) Aspect of creating a barrier-free building. They provides the stairs, and elevators to facilitate the transport of goods in the building.

From the eight criteria of ecological architecture that have been applied to the student dormitory design in Yogyakarta. There are two criteria that have not been applied in the design 
is the utilization criteria lining the walls and ceilings as greening component of building and criteria for the use of alternative renewable energy sources. From the table ablove, we know that application of ecological architecture concept of case study flat buildings has not become the main concept of university student dormitory building.

Recommendations from this study is that the design of student dormitory should be able to optimize the application of the concept of ecological architecture in all the design criteria Ecological Architecture. Moreover ecological architecture should be become building concept since conceptual phase of design by an architect. So it can give more advantages to student dormitory occupant.

\section{REFERENCES}

[1] Frick, Heinz. Dasar-dasar eko-arsitektur. Edisi ke-1. Yogyakarta: Yayasan Kanisius, 1998

[2] John M. Echols and Hassan Shadily, Kamus Inggris - Indonesia, Jakarta: P. T. Gramedia, 1975.

[3] Wikipedia, 2015

[4] Undang-undang RI No. 16 tahun 1985 tentang Rumah Susun. 